\title{
EL LEXEMA “ANGUSTIA” EN UN CORPUS DE LA LITERATURA COSTARRICENSE
}

\author{
Sonia Jones León
}

\section{RESUMEN}

En este artículo se analiza la presencia del lexema "angustia" y su influencia en la construcción de sentido en dos relatos del libro Cuentos de angustias y paisajes, de Carlos Salazar Herrera: "Un grito" y "El camino".

Palabras clave: Literatura costarricense, Carlos Salazar Herrera, Cuentos de angustias y paisajes, "angustia".

\begin{abstract}
This article analyzes the presence of the lexeme "anguish" and its influence in the construction of meaning in two tales from the book "Stories of Anguish and Landscapes" of Carlos Salazar Herrera: "A Scream" and "The Road".

Key words: Costa Rican literature, Carlos Salazar Herrera, Stories of Anguish and Landscapes, anguish.
\end{abstract}

Llegan con un pliego de papel, y con este pliego envolvieron todo cuanto encontraron

"Un Grito", Carlos Salazar Herrera.

Licda. Sonia Jones León. Profesora de la Escuela de Filología y Lingüística de la Universidad de Costa Rica. San Pedro, San José, Costa Rica.

Recepción: 08-05-05

Aceptación: 12-05-05 


\section{De la precipitación...}

En este artículo se analiza un corpus que consta de dos relatos del libro de Carlos Salazar Herrera, Cuentos de angustias y paisajes.

Constituyente del enunciado que un destinador comunica a su destinatario, la pregunta que me guía es ¿cómo se construye ese tejido que se propone desde el título como una conjunción entre angustia y paisaje?

El título de un texto, además de considerarse el nombre propio de este, funciona también como un programador de lectura. Además, todo título expande su significancia; es metonimia de él, es manifestación de lo publicado por el título.

En el caso que nos ocupa, el sintagma angustias y paisajes es conjuntivo, como lo es la metáfora. Entonces, el proyecto de comprensión que se propone incluye la posibilidad de comprender la angustia desde el paisaje y viceversa. Es decir, como metáfora. La función poética del lenguaje desde la cual se inscribe la metáfora responde a la pregunta ¿cómo está constituido el mensaje? Y, en lo específico, ¿cómo está constituida esa conjunción angustia y paisaje?, ¿qué otros recursos están en juego?

En el nivel semántico, la metáfora puede entenderse como una puesta en paréntesis de uno o varios núcleos de significación que permiten que el carácter conjuntivo de la metáfora (dos textualidades en juego) A=B, o A como B, permita, en un nivel profundo, desencadenar la intensificación del sentido y las posibilidades cognitivas que muchas veces la acercan al enigma.

En el caso de los cuentos escogidos, "El camino" y "Un grito", el juego de yuxtaposiciones entre las metáforas va creando una imagen hiperbólica o un exceso de sentido del que se desprende qué significa la angustia. Este exceso de sentido es el mecanismo que moviliza al personaje y al destinatario.

Transitaré primero por el cuento "El camino", a sabiendas de que me precipito por los abismos del sentido.

\section{2. "El camino"}

El narrador inicia el relato con una descripción de un camino de tierra colorada, que desde su perspectiva es "estrujado y profundo"; es un camino que "han tirado cuesta abajo, ahondándolo a fuerza viva, en el espinazo de la ladera”. Este camino es también un espacio "donde se derrumban precipicios llorando soledades". En estas imágenes se aprecian semas relacionados con lo animado y, más claramente, lo humanizado. Sigue yuxtaponiendo metáforas relacionadas con el mundo del ser humano: "La lluvia se puso a rodar piedras al declive". "La noche se quedó callada para oír los tumbos", "Tumbos en la noche, cortado en pedazos por los relámpagos", "el camino estaba hecho un río". Este paisaje, entonces, está comprendido como peligrosidad, movilidad, agudeza, luz, sombra, sonido/silencio. Todo ese universo engloba la posibilidad de caer, abismarse en alguno de los precipicios (irse de cabeza, según la etimología de esta palabra) que lloran soledades. La red de significantes construye una isotopía: una estructura caracterizada en sus polos por la vida/la muerte.

Una vez preparado, descrito este estado del paisaje en que priva la percepción de una subjetividad, la figura humana modela y se modela con la aparición en escena de una carreta de bueyes guiada por su boyero. 
Por ese camino bajaba una carreta. El boyero no podía detener a los bueyes que patinaban cuesta abajo, por el declive resbaladizo. La carreta llevaba un manteado. Debajo del manteado sonaban unos quejidos (...) Los quejidos eran de mujer (129).

Tejemos entonces de nuevo el paisaje: los tumbos que se detiene a escuchar la noche son también los de esta carreta que viene patinando, cuesta abajo: por analogía, esta carreta es una piedra más de las que la lluvia pone a rodar cuesta abajo. Pero, además, este destinador percibe junto con la noche los tumbos que interpreta así: "el golpe de los ejes en los cubos hacía ruido de matraca. Contestaban luego los barrancos. Era como si las montañas hubieran rezado". La tensión entre dos estados, el del tiempo y el del humano, se convierte en diálogo. Si examinamos la imagen significante de los ruidos de matraca, ésta produce un ruido grande y desapacible. Este instrumento se usa en Semana Santa en sustitución del sonido de las campanas, el Viernes Santo. Es el signo de muerte, duelo, de vigilia y de espera.

No obstante, este diálogo es relativo. Más bien es el eco del que se devuelve; el eco de la muerte es el que contestaban los barrancos: es monólogo solo posibilitado por dos estados que se conjuntan en uno solo. A esta altura del relato, lo construido podría comprenderse como "el paisaje de la angustia", una sola unidad sintagmática.

Ahora bien, ese paisaje no es estático. "Si el camino es un río", la angustia como estado genera una intensidad que se juega entre la vida y la muerte. Y así, siguiendo esta lógica propuesta desde el inicio del cuento, el exceso en uno de los polos o textos-estados hechos metáfora tiene que "rodar" hasta el final del relato, que cada vez se hace más a su propio silencio. Y así sucede.

\footnotetext{
Cayó de rodillas un buey. El impulso lo arrastró untándole el hocico de barro. El otro buey bufó de un dolor de pescuezo que se hundió en la tierra. La carreta se ladeó chillando junto a un paredón. El boyero se asomó bajo el manteado. La mujer estaba callada. Parecía dormida. ¡Era preciso llegar bien pronto donde el doctor! (130).
}

Esta percepción (doble, ya que el discurso indirecto libre conjunta la visión del personaje con la del narrador), evidencia aún más cómo cualquier contratiempo sería fatal e intensifica el paisaje de la angustia. El boyero resuelve el accidente de un solo chuzazo y la carreta comenzó a resbalar de nuevo, mordiendo la gravedad.

\section{Volvieron los quejidos}

La metáfora continúa siendo el medio intensificador de lo que yo llamaría "intermetaforización" entre angustia y paisaje. Sintácticamente, es yuxtaposición. No hay entonces enlaces conjuntivos que coordinen. Es difícil establecer esta marejada de sentidos que se combinan en la paleta de este descriptor.

Desde lo alto venían rodando piedras. La carreta tomaba velocidad. El boyero trotando de espaldas cogió por los cuernos a los animales que resbalaban con las patas estiradas hacia delante, combando el tronco, arrastrando los hocicos.

-...jJesa!... ¡Jesa!... ¡Jesa!...

En el saliente de un paredón, arrastrados por el declive, los cuatro cuernos de los bueyes quedaron ensartados. El yugo había prensado al boyero por el vientre. Allí quedó un momento sin resuello, mientras se fue escurriendo por entre las patas de los animales. Empezó a destorcerse, respiró hondo, con un estertor. Se puso de pie, y soltando otra maldición castigó a los bueyes (130). 
Luego, el inicio del sosiego. La aparente sintonía de los signos del texto paisaje y del texto interioridad-sentido.

La carreta resbaló nuevamente bajo los meteoros. Bajo los meteoros un poco sosegados. La tormenta fue
quedando atrás. El viento se alejaba, también la lluvia. La noche se disolvía. El camino menos empina-
do... El boyero. Los bueyes ¡La aurora! Se hizo de día (131).

El boyero logra poner en manos del médico a la mujer. Pero recordemos que ese paisaje de la angustia es una red significante que desde los primeros hilos teje una polaridadposibilidad de vida y muerte simultáneamente presentes; muestra suficientes indicios para que el sentido que ha sido tirado cuesta abajo hasta precipicios que lloran soledades, entre en la disyunción con la vida que se salva.

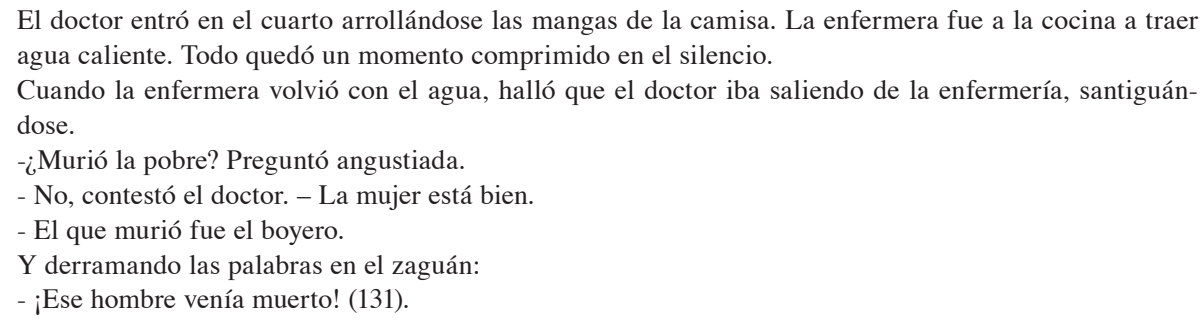

Si en el cuento "El camino", dos cuerpos posibilitan, con el recurso de la ironía, intercambiar el sentido (el enfermo se salva y "el sano" se muere), qué sucederá en otro texto como "Un grito", en el que también gracias a la metaforización y a la yuxtaposición, la angustia (¿será la misma o su nombre es legión?) queda descrita.

El narrador inicia el relato enunciando las pérdidas que ha sufrido un personaje del que sólo tiene el apellido: el paisaje, las altas cumbres de Santa María de Dota.

Lo había perdido todo. La tierra, la casa, el sembrado.

Todo lo había perdido. La voluntad, la ilusión, el tiempo. Hacia la mitad del día, entregó sus bienes al acreedor. Entregó íntegra su hacienda, junto con sus diez años de trabajo.

Su nombre... Matarrita (61).

O Matarrelato, si prefieren.

La causa: hipoteca de la finca a un logrero. Su primera reacción: no decir nada, ni una queja, ni una súplica. En palabras del narrador: "añadió una sonrisa y se guardó la pena". Luego decide partir hacia el atardecer.

A partir de ese instante, el paisaje empieza a ser percibido desde el estado interior de Matarrita. Se inicia la intermetaforización. De nuevo dos textos se ponen en juego reelaborándose a partir de la metáfora y la yuxtaposición. No es un texto comparado con otro, ni un texto en lugar de otro, ni un texto como otro.

En aquellas desordenadas cumbres, durante la época de las cilampas, el frío atormenta las articulaciones y desconsuela el espíritu. Matarrita se metió las orejas debajo del sombrero, se frotó la nariz y apretó con las piernas la panza del caballo, para calentarse con el vaho (62).

Continúa el matarrelato intensificando esta unidad. "El viento de agua, a una velocidad disparatada, aullaba como perros con miedo". Matarrita continúa su descenso. Decide incitar a los padres de su novia para contarles su fracaso y para aplazar la boda convenida. Cuando llega 
allí, nadie lo recibe y "la ventana se cierra en tanto que la puerta no se abre". "Bueno, se dijo mientras deambulaba su camino hacia El Empalme: esto también se acabó". Enrrumba hacia la casa de su padrino deseoso de tomarse un cafecito bien caliente pero (encuentra que):

\footnotetext{
Matarrita asomándose por una rendija del tabique, pudo ver que la casa estaba sola. Luego miró alrededor: había entorno como una pesadilla de desolación y abandono. Era el espectro de la borrasca que en las cimas desabrigadas, espanta a los montañeses que huyen buscando los bajíos (63-4).
}

Más allá, ni un rancho, ni un alma, ni un pájaro. Sólo el inmenso robledal fantástico y despiadado. El paisaje de la angustia despliega sus múltiples tonos disfóricos: el frío, la desolación, el miedo.

\title{
4. $\quad$ El texto de la angustia se despliega
}

\begin{abstract}
"Ahora, el viento de agua, en su trágica carrera cambiaba de paraje y por momentos se acumulaban monstruos de apretada niebla". La visión del narrador es una visión desde la interioridad. La intensificación de metáforas relacionadas con el tacto permitirían formular la angustia como un estado de intenso frío, agudo, filoso, percibido, por supuesto, desde la vida.

Los friolentos robles han tenido que cubrirse con musgos y los más añosos se dejaron crecer su "barba de viejo". En las axilas de las ramas tiritan las orquídeas y se descuelgan por los bejucos los quejidos del robledal. A veces la brisa del robledal lanza cuchillos de doble filo y con un estremecimiento, todo el robledal gotea... (64).
\end{abstract}

Llegado a El Empalme, Matarrita recuerda que el caballo no es suyo y continúa a pie... acompañado únicamente por "un lío de tristezas" (léase lío, como un enredo en la red significante). Esta puesta de los pies sobre la tierra le permite literalmente darse cuenta o sentir todo el peso de las pérdidas. Con ese lío a cuestas se extravía por un atajo estrecho y barroso, en el robledal, velado por la neblina. Se despliega, entonces, ante el lector, una especie de lienzo en que se pinta (recordemos que describir es, metafóricamente, pintar con palabras) a través de la mediación impresionista, caracterizada por ser una reproducción, que atiende lo que dicta la impresión subjetiva sobre la naturaleza, el paisaje de la angustia:

Iba tropezando con los bejucos y la maleza, que se prendía a sus piernas como plantas carnívoras. Iba deshecho, lamentablemente perdido, entre aquel tenebroso bosque de horcas con sus cuerdas colgando, mientras la noche se le venía encima, cargado de silencio (65).

Entumecido el cuerpo por el frío, turbia la mirada por la bruma, embotado el cerebro por las amarguras, tuvo de pronto la extraña impresión de que había muerto. Lo sorprendió el temor de que, en un arrebato inconsciente, se hubiese colgado de cualquier bejuco, aceptando la insistente invitación al suicidio que durante toda la tarde había venido susurrando una voz a sus espaldas. "Entonces creyó que debía convencerse a sí mismo de que aún no había muerto. Tenía que hacer algo para solucionar aquella necesidad de volver a la vida..."

De nuevo, en el tejido textual, hace presencia o se consolida como englobante semántico de la angustia la relación vida-muerte en estos relatos.

Si bien es cierto en el cuento "El camino" el descenso culmina con la manifestación de esta isotopía en dos corpus es objeto de la doble percepción. Quizá este paisaje de la angustia sea más confuso, por ser mayor, entonces, el exceso significante que caracteriza esta construcción y, por lo tanto, en la búsqueda de una salida, encontremos más referencias a cómo es la angustia de "estar ante la confusión lúcido". 


\section{Culminación de la precipitación o del despliego del metarrelato}

\begin{tabular}{|l|l|}
\hline \multicolumn{1}{|c|}{ Dice el texto: } & \multicolumn{1}{|c|}{ Contrario sensu: } \\
\hline "Algo que fuera como una liberación o un desahogo" & La angustia es como enajenación-angustia \\
\hline $\begin{array}{l}\text { "Algo para dar un hervor a la sangre y un consuelo } \\
\text { al alma" }\end{array}$ & $\begin{array}{l}\text { La angustia es enfriamiento, coagulamiento de la san- } \\
\text { gre (vida de la acción) }\end{array}$ \\
\hline "Algo para romper el silencio y espantar la tristeza" & $\begin{array}{l}\text { La angustia es incomunicación (ausencia de lenguaje } \\
\text { como comunicación, espanta la tristeza, imposibilidad } \\
\text { de decirla) (dar espacio a la no tristeza) }\end{array}$ \\
\hline $\begin{array}{l}\text { "Algo que tuviera, en un momento dado, el poder } \\
\text { milagroso de cambiar el espíritu demasiado confuso } \\
\text { de las cosas" }\end{array}$ & $\begin{array}{l}\text { Permanecer en angustia es un no saber excesivo que } \\
\text { desborda al sujeto: ¿La muerte en vida? "Un no poder } \\
\text { nombrar..." }\end{array}$ \\
\hline
\end{tabular}

El sujeto se debate en las imprecisiones: hacer algo como: ¿será la fuente: el no saber a pesar de que es sujeto es sabido? Y Matarrita (el matarrelato), lo encontró:

Se llenó los pulmones de aire, y soltó un prodigioso grito de alegría, que hizo temblar el robledal (65).

Salazar Herrera es, sin duda, uno de los mejores cuentistas de Latinoamérica, como puede colegirse del trabajo poético-estético que implica la mayoría de sus cuentos.

\section{Bibliografía}

Bonilla, Abelardo. 1967. Historia de la literatura costarricense. San José: Editorial Costa Rica.

Freud, Sigmund. 1981. "Inhibición, síntoma y angustia”. En Obras completas. Vol. III. Madrid: Editorial Biblioteca Nueva.

Le Guern, Michel. 1990. La metáfora y la metonimia. Madrid: Editorial Gredos.

Menton, Seymour. 1964. El cuento hispanoamericano. México: Fondo de Cultura Económica.

Salazar Herrera, Carlos. 1981. Cuentos de angustias y paisajes. 9na. edición. San José: Editorial Costa Rica. 